\title{
Announcements
}

\section{European Research Conferences}

\section{Provisional 1998 Programme}

The Programme of European Research Conferences is run by the European Science Foundation, mostly with funding from the Euroconferences Activity of the European Union. Each conference consists of a series of meetings, held typically every other year. There are neither written contributions nor proceedings. Unconventional ideas and new approaches, not yet fully explored, are encouraged. This is a provisional, selected announcement of the 1998 Programme of Conferences.

\section{Life Sciences}

Biophysics of Cytoskeleton: E. Sackmann (Garching) - Obernai (near Strasbourg), France, 22-27 April

Neural Mechanisms of Learning and Memory: Dynamics of the Trace: S. J. Sara (Paris) - Acquafredda di Maratea, Italy, 9-14 May**

Developmental Biology: The Genetic Control of Morphogenesis: R. Beddington (London) - Lenggries, Germany, 6-11 June

Gene Transcription in Yeast: Role of Chromatin and Transcription Factors: A. Sentenac (Gif-sur-Yvette) Granada, Spain, 11-16 September

Exocytosis: Membrane Dynamics in Exocytosis: Molecular Mechanisms: T. Kreis (Genève) - Giens (near Toulon), France, 26 September-1 October

\section{Biomedicine and Health}

Brain Development and Cognition in Human Infants: Development and Functional Specialization of the Cortex: M.-S. De Schonen (Marseille) - San Feliu de Guixols, Spain, 23-28 September

B Cells in Health and Disease: B Cells and Autoimmunity: F. K. Stevenson (Southampton) - Acquafredda di Maratea, Italy, 9-14 October

The conferences are open to researchers worldwide, whether from industry or academia. Participation will be limited to 100. The registration fee covers full board and lodging. Grants are available for younger scientists, in particular those from less favoured regions in Europe. Conferences marked by ** also have grants available for scientists from Central and Eastern Europe. 
For information and application forms contact the Head of the EURESCO Unit:

Dr. Josip Hendekovic

European Science Foundation

1 quai Lezay-Marnésia

F-67080 Strasbourg Cedex

France

Fax +33 388366987

e-mail: euresco@esf.org

on-line information and application on WWW at: http://www.esf.org/euresco

Cosponsored by the European Science Foundation and the Euroconferences Activity of the European Union.

\section{United Nations Educational, Scientific and Cultural Organization ICRO International Cell Research Organization}

\section{Unesco/ICRO Training Courses 1998}

Human Molecular Genetics, Sfax, Tunisia, 11-20 April

Organizer: Prof. Hammadi Ayadi, Faculté de Médecine de Sfax, 3028 Sfax, Tunisia, Fax + 2164246946 Frontiers in Reproduction: Molecular and Cellular Concepts and Applications, Woods Hole, USA, 28 May-4 July

Organizer: Dr. John Burris, Director, Marine Biological Laboratory, 7 MBL Street, Woods Hole, MA 02534-1015, USA, Fax + 1508457 1924, e-mail: jburris@mbl.edu

Molecular Approach toward Vaccine Development against Viral Infections, Yogyakarta, Indonesia, 17-30 June Organizer: Dr. Joedoro Soedarsono, Gadjah Mada University, Interuniversity Center for Biotechnology, Jl. Ternika Utara, Barek, Yogyakarta, Indonesia 56281, Fax +62 27463974

Molecular Biology of Cancer Cells, Nagoya, Japan, 6-17 July

Organizer: Dr. Shonen Yoshida, Research Institute for Disease, Mechanism and Control, Nagoya University School of Medicine, 65 Tsurumai-cho, Showa-ku, Nagoya 466, Japan, Fax +81 52744 2457, e-mail: syoshida@tsuru.med.nagoya-u.ac.jp

Embryogenesis: Fundamental Aspects and Cryobiological Principles Relating to Assisted Reproduction, Medunsa, South Africa, 27 July-12 August

Organizer: Dr. Johan Brinders, Dept. of Veterinary Physiology, Medical University of Southern Africa, P.O. Box 230, Medunsa, South Africa, Fax +27 12521 4270, e-mail: brinders@mcd4330.medunsa.ac.za

Biochemistry of Membrane Transport and Signal Transduction, Debrecen, Hungary, 16-29 August Organizer: Prof. Sandor Damjanovich, Dept. of Biophysics \& Cell Biology, University Medical School of Debrecen, Nagyerdei krt. 98, H-4012 Debrecen, Hungary, Fax +36 52412 623, e-mail: dami@jaguar.dote.hu

Molecular and Biotechnological Aspects of Sexual Reproduction in Higher Plants, Martonvasar, Hungary, 23 August-5 September

Organizer: Prof. Beata Barnabas, Agricultural Research Institute, P.O. Box 19, H-2462 Martonvasar, Hungary, Fax +3622460213

Membrane Receptors and Transmembrane Signal Transduction, Shanghai, China, 31 August-12 September Organizer: Prof. Q. S. Lin, Shanghai Institute of Biochemistry, Academia Sinica, 320 Yue-Yang Road, Shanghai 200031, China, Fax +862164335474 or 8357, e-mail: qslin@sunm.shcnc.ac.cn

Imaging and Microinjection of Aquatic Oocytes, Mombasa, Kenya, 5-18 September Organizer: Prof. Eliud N. Waindi, Dept. of Zoology, Maseno University College, Private Bag, Maseno, Kenya, Fax + 254 (0) 35 51221, e-mail: masenofs@arcc.or.ke 
Biomembranes and Molecular Medicine, Cluj-Napoca, Romania, 14-26 September

Organizer: Prof. Gheorghe Benga, "Iuliu Hatieganu" University of Medicine and Pharmacy, Dept. of Cell and Molecular Biology, 6 Pasteur St., 3400 Cluj-Napoca, Romania, Fax +40 64194373 or 197257

Current Trends in Microbial Technology for a Sustainable Environment, Kuala Lumpur, Malaysia, October Organizer: Dr. Sabaratnam Vikineswary, Institute of Postgraduate Studies and Research (IPSP), University Malaya, 50603 Kuala Lumpur, Malaysia, Fax +60 37568940

Long-Term Training Course on Selected Topics of Modern Biology, Szeged, Hungary, September 97-August 98 Organizer: Prof. Denés Dudits, Biological Research Centre, Institute of Genetics, P.O. Box 521, H-6701 Szeged, Hungary, Fax +36 62433 434, e-mail: dudits@everx.szbk.u-szeged.hu

Please apply directly to course organizers for information.

Proposals for 1999 training courses are welcome. Applications should include: detailed scientific programme including laboratory sessions, teaching staff and provisional budget and should be sent before 30 April 1998 to:

Prof. Georges N. Cohen

Executive Secretary

International Cell Research Organization (ICRO)

UNESCO House, SC/BSC

1 rue Miollis

F-75015 Paris

France

Fax +33145685818 or 40613550

e-mail: icro@unesco.org

or

e-mail: gncohen@pasteur.fr 